\title{
Research on Strengthening the Team Construction of College Organizer in the New Era
}

\author{
Yun Han* \\ College of Engineering and Technology \\ Tianjin Agricultural University \\ Tianjin, China \\ 396051786@qq.com \\ Yiming $\mathrm{Li}$ \\ College of Engineering and Technology \\ Tianjin Agricultural University \\ Tianjin, China \\ 421334362@qq.com
}

\author{
Yu Shi \\ College of Engineering and Technology \\ Tianjin Agricultural University \\ Tianjin, China \\ 95462845@qq.com \\ Hua Liu \\ College of Engineering and Technology \\ Tianjin Agricultural University \\ Tianjin, China \\ 41599386@qq.com
}

\begin{abstract}
This paper made the analysis from the two aspects: the current status of college organizer team construction in the new era and existing problems in the team construction, putting forward five effective measures to solve the research on the organizer team construction, strengthen the study and training, insist on the information and innovation, make a well-equipped and strong team and constantly establish related complete system of prizing and punishing to create an organizer team with certain professional working experience.
\end{abstract}

Keywords-organizer; team construction; research; new era; college

\section{INTRODUCTION}

The organization member is the party affairs worker that the party organization at all levels specializes in the party member development, the party member education and management, coordinating and dealing with the relationship between the party organizations at the higher and lower levels, and instructing the party organizations at the lower levels to carry out the organization work.

In the report of the nineteenth National Congress of the $\mathrm{CPC}$, the general secretary $\mathrm{Xi}$ Jinping pointed out that socialism with Chinese characteristics has entered a new era, and the new era is bound to produce new ideas and new theories-the socialist thought with Chinese characteristics in the new era of Xi Jinping. As an important position of ideological and political education, colleges and universities need to do a good job in ideological propaganda work, and strengthen ideological construction, the development of Party members, and the education management of Party members. They also need to improve the quality of the party members, cultivate and carry forward the socialist core values, to provide talent and intellectual support for the Chinese dream of the great rejuvenation of the Chinese nation. Therefore, the establishment of a special team with Party work experience and

Research on the Reform of Talent Cultivation Model of Engineering Major in Tianjin Agricultural College2017-B-00 Tianjin Agricultural College major education reform bidding project familiarity with party affairs is conducive to the correct implementation of the guiding ideology and guidelines for the development of Party members, the construction of the team of active members of the party, and the strict adherence to the standard of Party members[1]. We must ensure the quality of the newly developing party members and strive to unite outstanding young students under the party's banner, so that student party members can become more outstanding under the party's flag. At the same time, such a team has a very important role in understanding the ideological situation of the party members and assisting the organization department to grasp the education and management of the party members.

\section{THE CURRENT SITUATION OF THE CONSTRUCTION OF THE ORGANIZATIONAL STAFF IN COLLEGES AND UNIVERSITIES IN THE NEW ERA.}

In the new era, Chairman Xi Jinping stressed that our university is under the leadership of the party following socialist with Chinese characteristics[2]. It is necessary to focus on the builders, successors and young Marx advocates of the socialist cause, to maintain the party's advanced nature, strengthen the party's class foundation and expand the party's mass basis. Improving the creativity, cohesiveness and fighting capacity of the party organization, the party has put forward new requirements for the development of Party members and the education and management of Party members.

In recent years, with the continuous enrollment expansion of colleges and universities, the ratio of students and teachers has increased rapidly. Under the education of Party organizations at all levels, the enthusiasm for admission to the party is rising generally. The number of party activists, developing college student party members and staff members branches are increasing rapidly, which makes the scale of Party members and their training in colleges and universities, expand rapidly. It is important to organize college students and teachers to carry out party members' educational activities and party members' daily management, especially in training the 
party activists, screening key training objects, and the development and correction of Party members[3]. This puts forward higher requirements for the construction of the team of colleges and universities, and requires the overall quality of the party's party work team to meet the requirements of the educational work of the teachers and students in the new era.

At present, the Party committee of various colleges and universities conscientiously carry out the spirit of relevant documents and continuously strengthen the construction of the team members, so that the members of the organization become less to more. It has played an important role in the training of the party activists, the development of Party members and the innovation of the party building. It has made contribution to the direction of running a socialist university, strengthening and improving the ideological and political work of colleges and universities, cultivating qualified builders and reliable successors of the cause of socialism with Chinese characteristics, and building a beautiful and harmonious green campus of civilization. But there are still many problems that are not compatible with the new requirements of the new era, which have affected the construction of the organization staff.

\section{THE PROBLEMS EXISTING IN THE CONSTRUCTION OF THE ORGANIZATIONAL STAFF IN COLLEGES AND UNIVERSITIES IN} THE NEW ERA.

\section{A. University members are not clear about their roles.}

The role of a university organizer is a "coordinator" to assist the Party committee in the development of Party members, a "goalkeeper" to hold the entrance of a party member, and a "counselor" to carry out the educational activities of the party members. It is also a "administrator" for the effective management of Party members and a "supervisor" to supervise and guide the Party group to organize the work of the party. We should do a good job of the "guider" in building the ranks of activists who join the party. However, in practical work, some members of the organization have limited their work to one or more roles, ignoring the role of the whole. Some members of the organization have concentrated their energies and thoughts on other tedious and transactional jobs, and cannot play a good role in their work; some members simply position their roles directly into the party's grass-roots organizations' committee members and Party branch secretaries. Because of their unclear identity and unclear responsibilities, they have caused work loss, limitation, dislocation and so on. For example, some members of the organization often restrict their work to the development of a party member's work. They are concerned about the development of Party members and the collection and development of Party members, but not the development of the work of Party members as a systematic project, neglecting the construction of the party activists who join the party before joining the party, and absorbing all the links in the process of auditing and follow up education management and services after development.

\section{B. The strength of university staff is not complete enough.}

Because some grass-roots party organizations are not aware of the important position and function of the organization members in the party building work in colleges and universities, they are not in accordance with the requirements of the superior documents and systems to match the special and parttime staff to do the special purpose. They often arrange the organization staff to engage in some work outside their duties, which makes them, fail to study the deep problems in the organization development and Party building, adjust the work ideas and methods in time, innovate the work of the party and improve the working level according to the current situation development needs.

\section{The professional capability of the university staff should be strengthened.}

In recent years, colleges and universities have begun to be equipped with organizing members. However, because of the lack of business training and lack of experience in the work process, the new staff members lack innovation in their work. Due to the lack of learning and training related to the development of Party members and other related specialized knowledge, the education and training of the party activists, the development of Party members' working procedures and standards are not good enough, and some undue problems will often arise.

\section{The guarantee and incentive mechanism of university staff is not perfect enough.}

Nowadays, colleges and universities still have randomness in terms of the number and treatment of their members, and there is no guarantee mechanism for their study and promotion. First of all, because the organization members' work effectiveness is characterized by indirect, lagging and concealment, some assessment indicators are difficult to quantify and lack pertinence to the assessment of the organization's work; Secondly, the organization member's work principle and the policy is strong, and the degree of program and standardization is high, which often restrains the organization staff's work innovation, making the part organization feel boring and tired of the work. Thirdly, the work of the members is relatively simple. There is no special treatment and power, and some related policies are not well implemented. It is difficult to make outstanding achievements in work and get the recognition of leaders and masses. So the development and progress are restricted, and the enthusiasm of the organizers is affected.

\section{EFFECTIVE MEAsures FOR the CONSTRUCtion OF Organizing StafF IN COLLEGES AND Universities IN THE NEW ERA}

\section{A. Strengthening study to improve the theoretical and competence qualities of the organization members}

Holding high the great banner of socialism with Chinese characteristics, adhering to the guidance of Marxism-Leninism, Mao Zedong thought, Deng Xiaoping theory, the important thought of "three represents" and the scientific development view, to thoroughly study and implement the spirit of Comrade Xi Jinping's strategies of governing the country and managing government. Furthermore, the Party's educational policy should be comprehensively implemented, the socialist direction of running schools be adhered, and to cultivate people by virtue. 
Taking the ideal and believable education as the core, taking the socialist core values as the guide, as a result, the foundation could be strengthened, the weak board could be compensated, the business knowledge could be updated, and the level of Party building work could be raised in an all-round way. It is a must to strive to train qualified builders and reliable successors of socialism with Chinese characteristics, who possess both moral integrity and talent, also professional and reliable.

\section{B. Strengthening the training work and the professional level of the organizing staff in colleges and universities}

To combine the training of organization staff with the plan of teacher training and talents training in colleges and universities, to carry out team rotation training in an organized way, and to strengthen the tracking service by establishing and perfecting the training system of organization officers, in addition, the system should be updated regularly. The organization's political quality and professional level should be further improved, ensuring the organization's success. Members in the organization should complete the annual online and offline training tasks on time according to the requirements. They should timely and pertinently carry out specialized training on business knowledge so that their business ability could be improved, and they are able to adapt to new changes and developments. What's more, their ability and quality shall keep up with the changes to meet the needs of practical work.

\section{Persistence in reform and innovation, improving efficiency and practice to enhance the quality of work}

In their work, organizers should inherit and carry on the advantages of traditional work in order to adapt to new changes with time passing and promote the innovative forms of content. To enhance the working sense of time efficiency, we should always adhere to the working style of integrating theory with practice; consequently, we could walk out of the rules and regulations, to strengthen the guidance under organization members through practice[4]. Working methods should also be creative, so that the quality of work could be improved.

\section{Organizing staff to promote ideological and political work in colleges and universities}

It is the basic guarantee to improve the quality of developing Party members and strengthen the level of education and management of Party members. Each college should have at least one full-time organizer according to the ratio of not less than $1 \%$ of the total number of teachers and students, to further strengthen the work force of the grass-roots party organization in colleges[5].

\section{E. Constantly improve the guarantee and incentive mechanism of college organizing staff}

It is necessary to establish and perfect the evaluation and assessment of members, to combine the annual assessment with the usual assessment, and to link the assessment results with incentive measures, such as rewards and promotions. By setting up the assessment index reasonably, the organization member with outstanding achievements should be commended, while those who have no creation and achievements should be criticized, and those who are irresponsible should be adjusted. It is a must to ease the dilemma that the organization has less enthusiasm and teams are not so united[6]. The construction of personnel, wealth and material should be strengthened, and members are to be given evaluation, no matter it is positive or negative, the process should be fair. Also, members should be given moral or material stimulus to promote the development of them. Through the excellent and typical selection, publicity model deeds, a good atmosphere could be formed in the organization.

\section{CONCLUSION}

Through continuous study, especially the study of professional ability, organization members strengthen the training to innovate the training methods for organization officer, to promote accomplishment with the combination of meeting and training, and to strive for improving the ideological and political level. We should continue to improve the assessment mechanism of organizers through organizing special training courses, staff forums, subject research and professional training. Also, the organization's policy and party operational ability should be improved. To constantly explore the ideas of building the ranks of members and establish a special team with courage and experience of organization work and party affairs, it is conductive too carry out the guiding ideology and general requirements for the work of recruiting members in an all-round and correct manner. Finally, the ranks of party activists could be formed, the standards are adhered to strictly, and the quality of newly recruited party members could be ensured. At the same time, it is also conductive to understand the ideological situation of party members, which helps the organization departments to do a good job in the education and management of party members.

\section{ACKNOWLEDGMENT}

This work was financially supported by the Tianjin Agricultural College major education reform bidding project (2017-B-00).

\section{REFERENCES}

[1] Sun Xiaofeng. The innovative development of ideological and political work in colleges and universities with the leading of socialist core values[J]. Journal of Chizhou University,2017, 31(3):1-5;

[2] Wang Yongmei. To consolidate the guiding position of Marxis $m$ in the ideological field of colleges and universities[J]. Journal of Shenyang University, 2017, 19(5):600-604;

[3] Liu Qian. Reflections on the construction of the team of university organizers[J]. Journal of Daqing Nowmal University, 2013, 33(4): 160162;

[4] Tang Qiao and Dai Haoyun. Research on the ideological working ability of university leaders in the era of big data[J]. Journal of Chongqing University(the edition of society and technology), 2017(4):131-137.

[5] Chen Ming. Research on the evaluation of primary party organizations in colleges and universities [J] Science Tribune: the digital edition, 2013(6):41-42;

[6] Establish and improve the working mechanism of the organizer[J]. The theory of frontier, 2014, 3:226 